\title{
Analysis on the Competence and Influencing Factors of Financial Management Graduates
}

\author{
Wei Qinliu ${ }^{1, \text { a, * }}$, Zhou Ping ${ }^{2, b}$ \\ ${ }^{1}$ School of Economics and Management, Shanghai Second Polytechnic University, Jinhai Road 2360, \\ Shanghai, China \\ ${ }^{2}$ School of Modern Economic and management, Jiangxi University of Finance and Economics, Nanchang, \\ Jiangxi, China \\ àwqliu@sspu.edu.cn, b summerant@126.com \\ *corresponding author
}

Keywords: undergraduate, financial management, ability, influencing factors

\begin{abstract}
With the rapid development of economy in our country, the demand for excellent financial management professionals is growing, and the requirements are getting higher and higher, which poses new challenges to the cultivation of financial management professionals. This paper studies the cultivation of business graduates at home and abroad by analyzing a number of basic abilities to reflect the graduates of business major, then evaluate several important factors determinating their abilities through the investigation of financial management students of a university in Shanghai. We use the survey data and statistics analyzing software to examine the significant factors that affect the ability of financial management undergraduates.
\end{abstract}

\section{The Background and Significance of Survey}

\subsection{Survey Background}

The cultivation of financial management professionals is of vital importance to the development of the economy of the country. With the economic development in our country, the demand for excellent financial management professionals is growing. This puts forward new requirements and challenges to our country's financial management personnel training. Some western countries have advanced experience in training business students. We should learn from excellent business schools at home and abroad, take in excellent teaching experience to improve the teaching level of financial management.

In order to comply with the requirements of the times and national standards for teaching undergraduate of financial management, to improve the ability of financial management graduates, we conducted the survey to investigate the important factors affecting the ability of financial management undergraduates.

\subsection{The Significance of This Research}

Every year, there are many excellent business students graduating from the university of economics and management of a university in Shanghai. The financial management departent, in paticular, attracts many outstanding students. With the development of economy, the functions of risk control, investment and financing management, report analysis and internal control in financial management are becoming increasingly important for enterprises in various industries.

This survey mainly aims at students majoring in financial management who graduated in 2014, 2015 and 2016 respectively. The purpose of this study is to investigate and understand the significant factors influencing their practical ability in school. 


\section{The Characteristics of Financial Management Teaching}

\subsection{Strengthening General Education.}

Financial management students belong to the business category. Apart from basic and professional knowledge, students in business should also have certain knowledge in science, art, philosophy and history. At present, colleges and universities in western countries pay great attention to general education, which is devoted to imparting general knowledge and pursuing the interconnection of knowledge structures so as to activate the way of thinking, broaden the horizon and lay solid foundation for the future development of the students.

\subsection{Pay Attention to the Cultivation of Practical Ability.}

Students are required to have strong practical ability to engage in the professional work of financial management, and comprehensive problem-solving skills based on what they have learned.

\subsection{Focus on the Cultivation of Innovation Ability.}

In November 2015, the General Office of the State Council released the opinions on Deepening the Implementation of Innovation and Entrepreneurship Education Reform in Colleges and Universities. It is important to promote comprehensive reform in higher education and higher quality graduate employment in colleges and universities.

In addition, according to the National Standard of Undergraduate Teaching in Accounting, students should have good humanistic qualities, scientific spirit, good quality, professional accomplishment, teamwork spirit, learning ability and international vision.

\section{Investigation Planning}

\subsection{Questionnaire Content}

After several rounds of discussion with professional teachers, counselors, statistical experts and students, we make a questionnaire, which mainly contains the following aspects:

A. Have a general understanding of students at school. Is the student a party member? Is he/she a student cadre? How many after-tax incomes does the student have in the first year after graduation?

B. Reflect the ability of graduates. After reviewing the training objectives of commercial schools at home and abroad, we select the following abilities: executive ability, communication skills, teamwork skills, thinking and analytical skills, motivation to work and learning ability.

C. Theory teaching. We mainly focus on what the students' grade point are, how well they perform in their major, and how well the design of the course and their actual performance match.

D. Practice. On the school level, it is mainly about the effect of school practice teaching and the cooperation between the school and the enterprises. On the individual level of students, it mainly depends on whether they participated in the practice during the winter and summer vacations or whether they participated in student associations or volunteer activities when at school.

E. Innovative education. It is mainly about whether students participated in competition or innovation or entrepreneurship, and the evaluation by the students on that school's innovation ability.

F. School's performance in personality shaping, moral education, ideal stimulation and other aspects of the "spiritual" nurturing situation.

G. Student's advice.

\subsection{Methods and Forms of Investigation}

The questionnaire was distributed in the form of wjx.cn through WeChat, under the instrution of 
of the college director, counselors, teachers and statistics majors. The questionnaire was finally distributed by the counselor and the class cadres.

\subsection{The Object and Scope of the Investigation}

The survey was conducted by students majoring in financial management at a university in Shanghai. Students who graduated in 2014, 2015 and 2016 were selected.

\subsection{Research Methods}

SPSS single factor analysis was used. Single factor analysis is used to study whether the different levels of a factor have a significant effect on the observed variables. It is of statistical importance to examine whether the difference between the mean of one or several independent dependent variables is statistically significant.

The pre-condition of the use of univariate analysis method is as follows:

A. The randomness of the subject.

B. Normal distribution of dependent variables.

C. Homogeneity of variance, i.e., the overall variance at each level has the same variance.

When used, the homogeneity of the variance needs to be tested using the Homogeneity-ofvariance method. Using statistical inference ideas, the null hypothesis $\mathrm{H} 0$ is: no significant difference in the overall variance at all levels. By calculating the probability $\mathrm{P}$ value, the software makes the acceptance or rejection by comparing the $\mathrm{P}$ value and the level of significance. In the analysis of variance test, when $\mathrm{P}$ value is greater than the significance level 0.05 , the null hypothesis is accepted, and it is considered that different information sources have no significant influence on the mean value of the information transmission measurement; when $\mathrm{P}$ value is less than the significance level 0.05 , the null hypothesis is rejected, believing that different sources of information have a significant effect on the average measure of information dissemination.

\section{Data Statistics and Factor Impact Analysis}

\subsection{Description of Data Statistics}

General Situation

\subsubsection{The Number of Research}

A total of 123 questionnaires were collected, with two invalid questionnaires removed, so the actual effective questionnaire was 121 . The actual statistics are as shown in Table 1 . From the statistical data, the largest share was 2016; 2014 accounted for the smallest. The results should be close compared to the recent graduates.

Table 1 The Sample of Research

\begin{tabular}{|c|c|c|c|}
\hline Grade & Graduation & Survey & Investigation of proportion \\
\hline 2014 & 123 & 32 & $26.02 \%$ \\
\hline 2015 & 86 & 35 & $40.70 \%$ \\
\hline 2016 & 81 & 54 & $66.67 \%$ \\
\hline Total & 290 & 121 & $41.72 \%$ \\
\hline
\end{tabular}

\subsubsection{Population Statistics on Ability Self-Assessment}

The following Table 2 is a summary of the number of abilities. ABCD classification is classified from strong to weak. 
Table 2 Population Statistics on Ability Self-Assessment

\begin{tabular}{|c|c|c|c|c|c|c|}
\hline Grade & Executive & Communication & Teamwork & $\begin{array}{c}\text { Thinking } \\
\text { and } \\
\text { Analytical }\end{array}$ & Motivation & Learning \\
\hline A & 36 & 37 & 44 & 33 & 41 & 36 \\
\hline B & 70 & 65 & 71 & 72 & 46 & 74 \\
\hline C & 14 & 19 & 6 & 16 & 33 & 11 \\
\hline D & 1 & 0 & 0 & 0 & 1 & 0 \\
\hline
\end{tabular}

\subsubsection{Population Statistics on Factors Affecting the Ability}

The following Table 3 is a summary of population statistics on factors affecting the ability. The same ABCD classification is classified from strong to weak.

Table 3 Population Statistics on Factors Affecting the Ability

\begin{tabular}{|c|c|c|c|c|c|c|c|}
\hline Grade & Expertise & Curriculum & $\begin{array}{c}\text { Practical } \\
\text { Teaching }\end{array}$ & $\begin{array}{c}\text { Innovative } \\
\text { Training }\end{array}$ & $\begin{array}{c}\text { Associations or } \\
\text { Volunteer }\end{array}$ & $\begin{array}{c}\text { Vacation } \\
\text { Practice }\end{array}$ & $\begin{array}{c}\text { Spiritual } \\
\text { Cultivation }\end{array}$ \\
\hline A & 4 & 5 & 26 & 14 & 21 & 17 & 34 \\
\hline B & 61 & 92 & 59 & 54 & 40 & 42 & 55 \\
\hline C & 47 & 18 & 35 & 49 & 34 & 52 & 30 \\
\hline D & 9 & 6 & 1 & 4 & 26 & 10 & 2 \\
\hline
\end{tabular}

Description: Due to limited space, this section only lists the main data related to this article.

\subsection{Research Results}

According to the statistical results, we determine on the six competencies that reflect the financial management graduates and the factors that affect the six competencies. By means of the univariate analysis of SPSS software, the values of the four grades of ABCD are 1, 2, 3 and 4, finally, we draw the conclusion that the relevant ability and the school education influence each factor significantly. The summary of the table is as follows:

Table 4 Capability and Impact Factor Analysis Data

\begin{tabular}{|c|c|c|c|c|c|c|c|}
\hline Ability & Expertise & Curriculum & $\begin{array}{c}\text { Practical } \\
\text { Teaching }\end{array}$ & $\begin{array}{c}\text { Innovative } \\
\text { Training }\end{array}$ & $\begin{array}{c}\text { Associations or } \\
\text { Volunteer }\end{array}$ & $\begin{array}{c}\text { Vacation } \\
\text { Practice }\end{array}$ & $\begin{array}{c}\text { Spiritual } \\
\text { Cultivation }\end{array}$ \\
\hline Executive & 0.045 & 0.796 & 0.060 & 0.169 & 0.003 & 0.029 & 0.013 \\
\hline Communication & 0.411 & 0.013 & 0.535 & 0.037 & 0.043 & 0.003 & 0.000 \\
\hline Teamwork & 0.096 & 0.015 & 0.015 & 0.002 & 0.065 & 0.002 & 0.001 \\
\hline $\begin{array}{c}\text { Thinking and } \\
\text { Analytical }\end{array}$ & 0.188 & 0.166 & 0.061 & 0.003 & 0.004 & 0.009 & 0.000 \\
\hline Motivation & 0.001 & 0.008 & 0.022 & 0.000 & 0.295 & 0.005 & 0.001 \\
\hline Learning & 0.186 & 0.042 & 0.007 & 0.012 & 0.030 & 0.100 & 0.019 \\
\hline
\end{tabular}

According to the previous theory, all those with significance $\mathrm{P}<0.05$ were considered to have significant influence; conversely, the significance P value was greater than or equal to 0.05 were considered to have insignificant influence. The summarized form is shown in Table 5 below. 
Table 5 Capacity and Impact Factor Analysis Results

\begin{tabular}{|c|c|c|c|c|c|c|c|}
\hline Ability & $\begin{array}{c}\text { Expertise } \\
\text { ability }\end{array}$ & Curriculum & $\begin{array}{c}\text { Practical } \\
\text { teaching } \\
\text { effect }\end{array}$ & $\begin{array}{c}\text { Innovative } \\
\text { ability } \\
\text { training }\end{array}$ & $\begin{array}{c}\text { join } \\
\text { Acommunity } \\
\text { or volunteer }\end{array}$ & $\begin{array}{c}\text { Vacation } \\
\text { practice }\end{array}$ & $\begin{array}{c}\text { Spiritual } \\
\text { cultivation }\end{array}$ \\
\hline $\begin{array}{c}\text { Executive } \\
\text { ability }\end{array}$ & + & - & - & - & + & + & + \\
\hline $\begin{array}{c}\text { Communicat } \\
\text { ion skills }\end{array}$ & - & + & - & + & + & + & + \\
\hline $\begin{array}{c}\text { Teamwork } \\
\text { skills }\end{array}$ & - & + & + & + & - & + & + \\
\hline $\begin{array}{c}\text { Thinking and } \\
\text { analytical } \\
\text { skills }\end{array}$ & - & - & - & + & + & + \\
\hline $\begin{array}{c}\text { Motivation } \\
\text { to work }\end{array}$ & + & + & + & + & + & + \\
\hline $\begin{array}{c}\text { Learning } \\
\text { ability }\end{array}$ & - & + & + & + & + & + \\
\hline
\end{tabular}

Note: "+" stands for significance; "-" stands for insignificance.

Based on the above analysis of the impact of various abilities and teaching and practice aspects, the school's spiritual cultivation is closely related to each of the six abilities. It can be seen that it is very important to cultivate personality, morality and ideals, because these can support students' thoughts and behaviors. The cultivation of innovation ability is closely linked to the five abilities, showing that schools should also attach importance to the cultivation of innovative abilities. The practice of winter and summer vacations also significantly affect the six abilities, and the school should also pay attention to it. It is strange that the winter and summer vacation practice has little impact on the students' learning ability, because of which, some students were reacquainted with this. The fact lies in that in the holiday practice, a large proportion of students got involved in practice not related to their major.

After this result is obtained, further analysis is made on the school's scoring results of teaching and practice.

\subsection{Research Deficiencies}

A. The survey is conducted only from the perspective of the students, not from the aspect of the unit or the teacher. It is inevitable that some problems are subjectively underestimated.

B. Some issues are somewhat abstract, such as executive ability, communication skills, teamwork ability and other aspects. Inevitably there may be deviations from the actual.

C. The design questionnaire above is not comprehensive enough. For example, the morality of the working people is also important, but considering that the students may not answer this question objectively, it is not included.

\section{Conclusion}

Based on the investigation of three-year undergraduates, this paper selected six competencies and seven influential factors. After descriptive statistics of the questionnaire, this paper also crossanalyzed the competencies and various influencing factors, and obtained a significant degree of influence between the six abilities and the seven factors. After finding out the factors that affect the six abilities, we conclude with the students' ratings of the seven factors. We have come to the conclusion that all seven factors should be strengthened to some degree.

\section{References}

[1] National standard of accounting undergraduate education quality (third draft). 2014: 1.

[2] Wang Lu, Wang Qin, statistical software SPSS complete study manual and the actual combat essence. Chemical Industry Press .2013.3 